\title{
ANALYSIS OF NUGENT AND AMSEL CRITERIA FOR THE DETECTION OF FEMALE GENITAL TRACT INFECTIONS IN A TERTIARY CARE HOSPITAL, COASTAL KARNATAKA
}

Kumari Nisha1, Beena Antony²

${ }_{1}^{1}$ Research Scholar, Department of Microbiology, Fr. Muller Medical College and Hospital, Mangaluru.

2Professor, Department of Microbiology, Fr. Muller Medical College and Hospital, Mangaluru.

\section{BACKGROUND}

ABSTRACT

Female genital tract infections are polymicrobial in nature. Among the genital infections, bacterial vaginosis is the most common infection caused by anaerobic and microaerophilic organisms such as Bacteroides fragilis group, Mobiluncus species, Porphyromonas species, Prevotella group and Gardnerella vaginalis.

Objective- Comparative evaluation of Nugent and Amsel criteria in diagnosis of various types of female genital tract infections.

\section{MATERIALS AND METHODS}

The present descriptive study was conducted in a tertiary care hospital in coastal Karnataka, South India during the period from July 2013 to June 2016. Of the 1217 women under study, 1054 cases were taken with complaints of vaginal discharge and 163 were included as control, which belongs to normal vaginal flora, confirmed by microscopy in the Dept. of Microbiology, Father Muller Medical College, Mangalore. High vaginal swabs from women of reproductive age group (15 - 45 years) and 163 age matched control group were examined by preliminary examination.

\section{RESULTS}

By employing Amsel and Nugent criteria, out of 1054 vaginal samples $415(39.4 \%)$ were Normal vaginal flora, Vaginal Lactobacillosis 117 (9.3\%), Bacterial vaginosis 315 (29.9\%), Intermediate Bacterial vaginosis 11 (1.0\%), Vulvovaginitis 6 (0.6\%), Cervicitis 4 (0.4\%), HIV 2 (0.2\%), Candidiasis 106 (10.1\%), Group B Streptococcus with Antenatal cases 73 (6.9\%) and Trichomoniasis $5(0.5 \%)$. No vaginal infections were detected from the control group.

\section{CONCLUSION}

BV, Candidiasis, Trichomoniasis and Vulvovaginitis are the most common conditions present among female genital tract infections. Nugent and Amsel criteria are the most cost effective and less time-consuming tests for the diagnosis of vaginal infections.

\section{KEYWORDS}

Nugent's Criteria, Amsel's Criteria, Bacterial Vaginosis, Vaginal Discharge Candidiasis, Trichomoniasis.

HOW TO CITE THIS ARTICLE: Nisha K, Antony B. Analysis of Nugent and Amsel criteria for the detection of female genital tract infections in a tertiary care hospital, Coastal Karnataka. J. Evolution Med. Dent. Sci. 2018;7(06):742-746, DOI: $10.14260 /$ jemds/2018/168

\section{BACKGROUND}

The normal vaginal flora of women includes abundant prevalence of Lactobacilli, which maintain vaginal $\mathrm{pH}$ and acidic environment of vagina. ${ }^{1}$ Lactobacilli are considered to play a pivotal role in preventing the overgrowth of other bacteria by production of lactic acid. The Lactobacilli maintain their dominance through combination of acidity, hydrogen peroxide, lactocins and other bacteriocin which inhibit the growth of other bacteria. ${ }^{2}$ Female genital tract infections characterised by the reduction in the prevalence number of hydrogen peroxide producing Lactobacilli and overgrowth of vaginal microbiota include viruses, bacteria, parasites and fungi. ${ }^{3}$

Female genital tract infection is polymicrobial in nature and microorganisms are classified as in three forms such as-

'Financial or Other Competing Interest': None.

Submission 30-12-2017, Peer Review 22-01-2018,

Acceptance 29-01-2018, Published 05-02-2018.

Corresponding Author:

Dr. Beena Antony,

Professor, Department of Microbiology,

Fr. Muller Medical College and Hospital,

Kankanady P. O. Mangaluru-575002, South Karnataka.

E-mail: beenafmmc@gmail.com

DOI: $10.14260 /$ jemds $/ 2018 / 168$
1. Sexually transmitted disease (STD) organisms which include Neisseria gonorrhoeae, Chlamydia trachomatis, Herpes simplex and Trichomonas vaginalis,

2. Mixed aerobes and anaerobes,

3. Mycoplasma hominis and Ureaplasma urealyticum. ${ }^{4}$

In genital infection, mixed aerobes and anaerobes cause bacterial vaginosis (BV), vulvovaginitis, tubo-ovarian abscess, cervicitis, postsurgical and post-partum infections. Of these infections BV is the most common infection found in vaginal tract which causes vaginal discharge and thus leading to vaginal disorder in women of reproductive age.5,6

The present study was intended to perform the comparative evaluation of Nugent and Amsel criteria in diagnosis of various types of female genital tract infections in a tertiary care hospital, Karnataka.

\section{MATERIALS AND METHODS}

The present descriptive study was conducted in a tertiary care hospital in Coastal Karnataka, South India, during the period from July 2013 to June 2016. Ethical clearance was obtained for the study (Ref. No. FMCC/ FMIEC/ 1298/ 2013) and written informed consent was duly collected from the patients or attendants. 


\section{Source and Collection of Data}

High vaginal swabs from 1054 women of the reproductive age group in the $(15-45)$ were suspected to have BV and other female genital tract infections such as itching, irritation or burning, discomfort urination, douching, using contraceptive device, infertility cases, pre-term birth and pelvic inflammatory disease constitute the test. Control group number 163 included from healthy women in the reproductive age group without any white discharge, attending for family planning consultation were collected from the Department of Gynaecology and Obstetrics. Nonrandom, convenient sampling technique was used.

A detailed clinical history for each woman was noted which included age, sex, severity of problem and other illnesses etc. were taken from medical records. Women with menstrual period and patients who were on medication and clinically diagnosed for any bacterial, fungal, parasitic or viral infections for upto one month prior to the specimen collection and women with diabetes mellitus were excluded from the study.

Three high vaginal swabs were collected per patient aseptically. Vaginal secretions or discharge were collected from the posterior and lateral fornices cervix area. Cervical or high vaginal swabs were collected with the help of Cusco's speculum and inoculated into sterile tube containing $0.5 \mathrm{~mL}$ normal saline and immediately transported to the Department of Microbiology for the further processing.

\section{Diagnosis of Female Genital Tract Infections}

Diagnosis was done based on Amsel and Nugent criteria.

\section{Amsel's Criteria}

The Vaginal Discharge was subjected to the following Tests-

a. Appearance: Appearance of the discharge was clear to white and homogeneous.

b. pH Test: $\mathrm{pH}$ of the discharge was tested by using $\mathrm{pH}$ paper, which showed a wide pH range of 1 - 14 (HiMedia Laboratories, Pvt. Ltd., Mumbai, India).

c. Whiff Test: Microorganisms produced amines, which is present in the vaginal discharge. The organisms which involved in BV volatilise in the presence of alkaline $\mathrm{pH}$ giving a fishy smell.

d. Clue Cells: Presence of clue cells were confirmed by screening the vaginal discharge by gram stain. Clue cells are the vaginal squamous epithelial cells studded with large number gram variable coccobacillary forms.

e. According to Amsel's Criteria: According to Amsel's Criteria: If three of the above four criteria were positive, the patient was considered to be suffering from female genital tract infections. ${ }^{7}$

\section{Procedures:}

\section{pH Determination}

A swab of vaginal discharge was put onto litmus paper to check its acidity. A colour reaction developed on the paper was compared to a colour comparison chart to determine the $\mathrm{pH}$ of the sample. $\mathrm{pH}>4.5$ indicated $\mathrm{BV}$.

\section{Amine Odour Test (Whiff Test)}

Amines present in the vaginal discharge produced by the microorganisms were involved in BV. A drop of $10 \%$ potassium hydroxide $(\mathrm{KOH})$ was added to some vaginal discharge put in a clean glass slide. A characteristic fishy odour was considered as positive amine odour test and was suggested of BV.

\section{Wet Mount}

A drop of vaginal discharge suspension was placed on a slide and covered with coverslip. Slide was examined microscopically using a 40x objective. Test was analysed for determination of epithelial clue cells and pus cells, $T$. vaginalis (TV) and Candida specie.

\section{Nugent Score and Interpretation Criteria Gram Stain}

High vaginal discharge smeared on clean glass slides, air dried, heat fixed and stained by Gram's method using acetone alcohol (1: 1) mixture as decolouriser and dilute carbol fuchsin as the counter stain. The numbers of "clue" cells, various morphotypes of bacteria and normal epithelial cells were estimated. 8

\section{Nugent's Criteria}

Nugent criteria is a gold standard method for detection of female genital tract infections, which is based on interpretation of Gram stain of vaginal discharge. Nugent criteria summed the weighted quantitation $(0,1$ to $4+)$ of the following morphotypes to yield a score of 0 to 10 for each case, large gram-positive rods (Lactobacillus morphotypes weighted such that absence yielded the highest score), small gram-negative to gram-variable rods ( $G$. vaginalis and Bacteroides spp. morphotypes) and curved gram-variable rods (Mobiluncus spp. morphotypes). The criterion for bacterial vaginosis was a score of 7 or higher, a score of 4 to 6 was considered intermediate and a score of 0 to 3 was considered normal. 9 Table 1 and 2 shows the Nugent's criteria methods. In the present study, Nugent's criteria method was considered as gold standard method compared to Amsel's criteria.

\section{Statistical Analysis}

Statistical analysis was done using SPSS version 23. Fisher's exact test was applied for data analysis and Chi-square test used for comparative analysis between Amsel and Nugent criteria. The sensitivity, specificity, positive predictive value and negative predictive value were calculated by Chi-square test.

\section{Nugent Score an Interpretation Criteria}

\begin{tabular}{|c|c|c|c|c|c|}
\hline Morphotype & \multicolumn{5}{|c|}{$\begin{array}{c}\text { Number of Organism per Oil } \\
\text { Immersion Field (Average } 10 \text { Field) }\end{array}$} \\
\hline \multirow{2}{*}{$\begin{array}{l}\text { Lactobacillus } \\
\text { species }\end{array}$} & None & $<1.0$ & $1-4$ & $5-30$ & $>30$ \\
\hline & 4 & 3 & 2 & 1 & 0 \\
\hline $\begin{array}{l}\text { Gardnerella and } \\
\text { Anaerobic GNB }\end{array}$ & 0 & 1 & 2 & 3 & 4 \\
\hline $\begin{array}{c}\text { Curved GNB } \\
\text { Mobiluncus Species }\end{array}$ & 0 & 1 & 1 & 2 & 2 \\
\hline \multicolumn{6}{|c|}{ Table 1} \\
\hline
\end{tabular}




\begin{tabular}{|c|c|c|}
\hline $\begin{array}{c}\text { Nugent's } \\
\text { Score }\end{array}$ & $\begin{array}{c}\text { Cells Present or } \\
\text { Absent }\end{array}$ & Interpretation \\
\hline $0-3$ & No clue cells & Normal vaginal flora \\
\hline $4-6$ & No clue cells & $\begin{array}{c}\text { Intermediate or not } \\
\text { consistent with BV }\end{array}$ \\
\hline $4-6$ & Clue cell present & Indication of BV \\
\hline$\geq 7$ & $\begin{array}{c}\text { Clue cell present or } \\
\text { absent }\end{array}$ & Indication of BV \\
\hline \multicolumn{3}{|c|}{ Table 2 } \\
\hline
\end{tabular}

\section{RESULTS}

Of the 1217 women under study, 1054 cases were taken with complaints of vaginal discharge and 163 were included as control which belongs from normal vaginal flora. High vaginal swabs were examined by Amsel and Nugent criteria.

Table 3 shows details of age-wise distribution of cases and controls. Table 4 indicates preliminary examination of 1054 vaginal samples such as Trichomonas vaginalis 5 (0.5\%), G. vaginalis 223 (21.2\%) and Candida spp. 106 (10.1\%). Table 5 shows results of female genital tract infections prevalent in 1054 cases with 163 age matched control group.

Table 6 shows comparison results of Amsel and Nugent criteria in female genital tract infection cases. The sensitivity, specificity, positive predictive value and negative predictive value were calculated which indicates Nugent's criteria is the best method for diagnosis of female genital tract infections compared to Amsel's criteria.

\begin{tabular}{|c|c|c|c|c|c|c|}
\hline \multirow{2}{*}{$\begin{array}{l}\text { Age Group } \\
\text { in Year }\end{array}$} & \multicolumn{4}{|c|}{ Groups } & \multirow{2}{*}{ Total } & \multirow[b]{2}{*}{ (\%) } \\
\hline & Cases & $\%$ & Control & $\%$ & & \\
\hline 16 to 20 & 56 & 5.3 & \begin{tabular}{|l|l}
6 \\
\end{tabular} & 3.7 & 62 & 5.1 \\
\hline $21-30$ & 413 & 39.2 & 72 & 44.7 & 485 & 39.9 \\
\hline $31-40$ & 283 & 26.9 & 47 & 28.8 & 330 & 27.1 \\
\hline Above 40 & 302 & 28.7 & 38 & 23.3 & 340 & 27.91 \\
\hline Total & 1054 & 100.0 & 163 & 100.0 & 1217 & 100.0 \\
\hline \multicolumn{7}{|c|}{$\mathrm{X} 2=3.265, \mathrm{p}=.353$, not significant } \\
\hline \multicolumn{7}{|c|}{$\begin{array}{l}\text { Table 3. Details of Age-Wise distribution of Cases and } \\
\text { Controls }\end{array}$} \\
\hline
\end{tabular}

\begin{tabular}{|c|c|c|c|c|c|c|c|}
\hline \multirow{2}{*}{\multicolumn{2}{|c|}{ Groups }} & \multicolumn{2}{|c|}{ Positive } & \multicolumn{2}{|c|}{ Negative } & \multirow{2}{*}{\multicolumn{2}{|c|}{$\begin{array}{l}\text { Fisher Exact } \\
\text { Test p value }\end{array}$}} \\
\hline & & \multirow{2}{*}{\begin{tabular}{|c|} 
No. \\
5 \\
\end{tabular}} & \multirow{2}{*}{$\begin{array}{c}\% \\
0.5 \\
\end{array}$} & \multirow{2}{*}{$\begin{array}{c}\text { No. } \\
1049 \\
\end{array}$} & \multirow{2}{*}{$\begin{array}{c}\% \\
99.5 \\
\end{array}$} & & \\
\hline \multirow{2}{*}{$\begin{array}{c}\text { Trichomonas } \\
\text { Vaginalis (TV) }\end{array}$} & Cases & & & & & \multirow[b]{2}{*}{.487} & \multirow{2}{*}{\begin{tabular}{|c|} 
Not \\
Signifi- \\
cant
\end{tabular}} \\
\hline & Control & 0 & 0.00 & 163 & 100.0 & & \\
\hline \multirow{2}{*}{$\begin{array}{l}\text { G. vaginalis } \\
\text { (GV) }\end{array}$} & Cases & 223 & 21.2 & 831 & 78.8 & \multirow[b]{2}{*}{.000} & \multirow{2}{*}{$\begin{array}{c}\text { High } \\
\text { Signifi- } \\
\text { cant }\end{array}$} \\
\hline & Control & 0 & 0.00 & 163 & 100.0 & & \\
\hline \multirow{2}{*}{ Gonococci (G) } & Cases & 0 & 0.00 & 1054 & 100.0 & \multirow[b]{2}{*}{-} & \\
\hline & Control & 0 & 0.00 & 163 & 100.0 & & \\
\hline \multirow{2}{*}{$\begin{array}{l}\text { Candida spp. } \\
\text { (C) }\end{array}$} & Cases & 106 & 10.1 & 948 & 89.9 & \multirow[b]{2}{*}{.000} & \multirow{2}{*}{$\begin{array}{c}\text { High } \\
\text { Signifi- } \\
\text { cant }\end{array}$} \\
\hline & Control & 0 & 0.00 & 163 & 100.0 & & \\
\hline & & $\ldots$ & 8 & $\begin{array}{l}\text { atio } \\
\text { abs }\end{array}$ & $T V$, & & \\
\hline
\end{tabular}

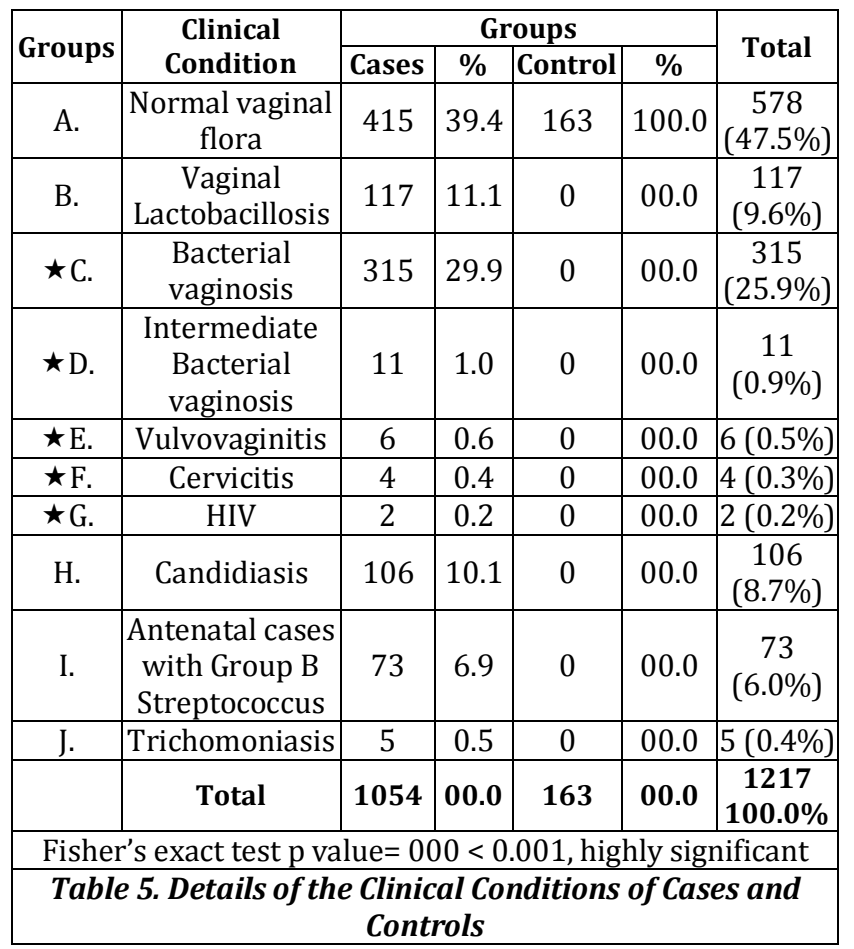

\begin{tabular}{|c|c|c|c|c|}
\hline Methods & $\begin{array}{c}\text { Sensitivity } \\
\%\end{array}$ & $\begin{array}{c}\text { Specificity } \\
\%\end{array}$ & $\begin{array}{c}\text { Positive } \\
\text { Predictive } \\
\text { Value \% }\end{array}$ & $\begin{array}{c}\text { Negative } \\
\text { Predictive } \\
\text { Value \% }\end{array}$ \\
\hline $\begin{array}{c}\text { Amsel's } \\
\text { criteria }\end{array}$ & 57.72 & 98.79 & 78.61 & 96.81 \\
\hline $\begin{array}{c}\text { Nugent's } \\
\text { criteria }\end{array}$ & 96.81 & 78.61 & 57.72 & 98.79 \\
\hline Table 6. Comparison of Amsel and Nugent Methods from \\
Female Genital Tract Infections \\
\hline
\end{tabular}

\section{DISCUSSION}

Female genital tract infections include a spectrum of clinical conditions such as Bacterial vaginosis, Pelvic inflammatory disease, Trichomoniasis, Vulvovaginitis, Candidiasis etc. BV is found to be the most common vaginal disorder in women of reproductive age. BV can predispose to obstetrical infections, post aortal, pelvic inflammatory disease, post-partum endometritis after caesarean, prevalence of BV obtained in patients with infertility, preterm labour.10

Initial screening of these infections was done by direct microscopy. As implied in the literature, Amsel's criteria is less sensitive than gram stain interpretation in cases of BV.7,11 Amsel's criteria requires a minimum of 3 to 5 vaginal swabs from each patient.12,13 It has been observed that routinely only a single swab is sent to the laboratory to rule out BV in the hospitals. This might be the reason why Amsel's criterion is unpopular. Ever though culture is the gold standard, the organisms present in the specimen do not survive the delay in processing. Hence, gram stain interpretation is the most popular method for routine diagnosis of vaginal infections.

Previous studies reported that Nugent's criteria is the best method for diagnosis of BV. ${ }^{14-16}$ Based on direct smear examination, it can classify gram vaginal smears into normal vaginal flora, intermediate BV and BV. The standardised score had improved Spiegel criteria, which divides gram stain into two categories- normal vaginal flora and BV.9,17 Few studies have tried to formulate that gram stain scoring system was better, but are not popular as Nugent's criteria for diagnosis of BV.18,19 
Kusters and their colleagues performed a comparative study by using a multiplex real-time PCR assay and Nugent's score diagnosis of BV. ${ }^{20}$ They reported that multiplex qPCR was a better method for diagnosis of BV compared to the Nugent's score.

In the present study, Amsel criteria and Nugent criteria were compared for the diagnosis of female genital tract infections. In comparison with Amsel's method, Nugent's Criteria was found to be $96.81 \%$ sensitive, $78.61 \%$ specific with positive predictive value of 57.72 and negative predictive value of $98.79 \%$. In the present study, Nugent's criteria were found to be gold standard method compared to Amsel's criteria p .000, highly sensitive.

In a study by Udayalakshmi J et al, Amsel's criteria, Spiegel's and Nugent's criteria are reported equally effective methods for the diagnosis of BV,21 whereas another study reported Amsel's criteria is less sensitive to Nugent's criteria. 7,11

Indian studies conducted on general population have shown the prevalence of BV as $19 \%$ by Nugent's scoring system. ${ }^{21-23}$ In a previous Indian study the prevalence of BV was observed as the highest in Urban slum 38.6\%, Rural $28.8 \%$ and Urban middle class community $25.4 \% .^{24,25}$ However, the present study conducted on the Rural and Urban middle class community has shown the prevalence of BV $29.9 \%$ and Intermediate BV $1 \%$ by Nugent's scoring system.

Vaginal Lactobacillosis is a condition mostly found in the reproductive age group of women with odourless, white vaginal discharge and vulvovaginal itching. In a study reported by Ventolini G 15\% prevalence of Vaginal Lactobacillosis in women, ${ }^{1}$ whereas the present study was observed a prevalence of $11.1 \%$ Vaginal Lactobacillosis.

A study reported by Doyle C and their colleagues, Trichomonas vaginalis was significantly associated from premenstrual syndrome with headache. ${ }^{26}$ However, some other studies have reported $4 \%{ }^{21}$ and $1.5 \%{ }^{27}$ Trichomoniasis from infectious women. In the present study, $5(0.5 \%)$ Trichomoniasis was observed.

Dagli and Demir had reported Candida spp. (7.3\%),28 whereas in other studies Candidiasis was obtained in $20 \% 21$ and $16.5 \%{ }^{27}$ respectively. In present study, $10.1 \%$ Candida species was analysed from the genital tract infections. Powell and Nyirjesy reported some of the commonly encountered problems in women like Vulvovaginitis, Vulvovaginal Candidiasis, BV and Trichomoniasis. ${ }^{29}$

The present study evaluates the value of direct and preliminary examinations of vaginal discharge from infectious women by using Nugent and Amsel criteria. The time required to diagnose female genital tract infections by culture and other sophisticated newer methods will require longer time. Therefore, our study employs cost effective and less time-consuming methods to analyse these infections by Gram stain, $\mathrm{pH}$ test, whiff test and wet mount.

\section{CONCLUSION}

Female genital tract infections namely BV, Candidiasis, Trichomoniasis and Vulvovaginitis affect the socio-economic conditions of the women in India. Nugent and Amsel criteria are the most cost effective and less time-consuming methods for the diagnosis of such vaginal infections as compared to the traditional culture technique.

\section{ACKNOWLEDGEMENT}

The authors would like to acknowledge Dr. Annie, Dr. Prema, Dr. Deepa and Dr. Mahesh from Dept. from Gynaecology, Father Muller Medical College for the support extended during collection of vaginal samples.

\section{REFERENCES}

[1] Ventolini G, Schrader C, Mitchell E. Vaginal lactobacillosis. J Clin Gynecol Obstet 2014;3(3):81-4.

[2] Boris S, Suarez JE, Vazquez F, et al. Adherence of human vaginal lactobacilli to vaginal epithelial cells and interaction with uropathogens. Infect Immun 1998;66(5):1985-9.

[3] Sobel JD. Bacterial vaginosis. Annu Rev Med 2000;51:349-56.

[4] Finegold SM, George WL. Female genital tract infections. Chapter 19. In: Finegold SM, George WL. eds. Anaerobic infectious in human. $1^{\text {st }}$ edn. California: Academic Press Limited, 1989:429-55.

[5] Gergova RT, Strateva TV, Mitov IG. Gardnerella vaginalis-associated bacterial vaginosis in Bulgarian women. Braz J Infect Dis 2013;17(3):313-8.

[6] Rein MF. Vulvovaginitis and cervicitis. In: Mandell GL, Bennett JE, Dolin R. eds. Principles and practice of infectious diseases. $5^{\text {th }}$ edn. United States of America: Churchill Livingstone, Harcourt Inc., 2000:1218-34.

[7] Amsel R, Totten PA, Spiegal CA, et al. Non-specific vaginitis. Diagnostic criteria and microbial and epidemiological associations. Am J Med 1983;74(1):14-22.

[8] Blackwell A, Barlow D. Clinic diagnosis of anaerobic vaginosis (non-specific vaginitis). A practical guide. $\mathrm{Br}$ J Vener Dis 1982;58(6):387-93.

[9] Nugent RP, Krohn MA, Hillier SL. Reliability of diagnosing bacterial vaginosis is improved by a standardized method of Gram stain interpretation. J Clin Microbiol 1991;29(2):297-301.

[10] Catlin BW. Gardnerella vaginalis characterisitics, clinical considerations and controversies. Clin Microbiol Rev 1992;5(3):213-37.

[11] Sha BE, Chen HY, Wang QJ, et al. Utility of Amsel criteria, Nugent score and quantitative PCR for Gardnerella vaginalis, Mycoplasma hominis and lactobacillus spp. for diagnosis of bacterial vaginosis in human immunodeficiency virus-infected women. J Clin Microbiol 2005;43(9):4607-12.

[12] Ferris DG, Francis SL, Dickman ED, et al. Variability of vaginal $\mathrm{pH}$ determination by patients and clinicians. J Am Board Fam Med 2006;19(4):368-73.

[13] Cohrssen A, Anderson M, Merrill A, et al. Reliability of the whiff test in clinical practice. J Am Board Fam Pract 2005;18(6):561-2.

[14] Cox C, Watt AP, McKenna JP, et al. Mycoplasma hominis and Gardnerella vaginalis display a significant synergistic relationship in bacterial vaginosis. Eur J Clin Microbiol Infect Dis 2016;35(3):481-7.

[15] Kosnik GI, Dermota U, Golle A. Frequency of detection of Gardnerella vaginalis in vaginal smears in the upper carniola region. Acta Dermatovenerol Alp Pannonica Adriat 2016;25(2):31-3. 
[16] Datcu R, Gesink D, Mulvad G, et al. Vaginal microbiome in women from Greenland assessed by microscopy and quantitative PCR. BMC Infect Dis 2013;13: p. 480.

[17] Spiegal CA, Amsel R, Holmes KK. Diagnosis of bacterial vaginosis by direct gram stain of vaginal fluid. J Microbiol 1983;18(1):170-7.

[18] Ison CA, Hay PE. Validation of a simplified grading of Gram stained vaginal smears for use in genitourinary medicine clinics. Sex Transm Infect 2002;78(6):413-5.

[19] Verhelst R, Verstraelen H, Claeys G, et al. Comparison between Gram stain and culture for characterization of vaginal microflora: definition of a distinct grade that resembles grade 1 microflora and revised categorization of grade 1 microflora. BMC Microbiol 2005;51:61.

[20] Kusters JG, Reuland EA, Bouter S, et al. A multiplex real-time PCR assay for routine diagnosis of bacterial vaginosis. Eur J Clin Microbial Infect Dis 2015;34(9):1779-85.

[21] Udayalakshmi J, Bhat GK, Kottigadde S. Biotypes and virulence factor of Gardenella vaginalis isolated from cases of bacterial vaginosis. Indian J Med Microbiol 2011;29(2):165-8.

[22] Madhivanan P, Krupp K, Chandrasekaran V, et al. Prevalence and correlates of bacterial vaginosis among young women of reproductive age in Mysore, India. Ind J Med Microbiol 2008;26(2):132-7.
[23] Rao PS, Devi S, Shriyan A, et al. Diagnosis of bacterial vaginosis in a rural set up: comparision of clinical algorithm, smear scoring and culture by semiquantitative technique. Ind $\mathrm{J}$ Med Microbiol 2004;22(1):47-50.

[24] Bhalla P, Chawla R, Garg S, et al. Prevalence of bacterial vaginosis among women in Delhi, India. Indian J Med Res 2007;125(2):167-72.

[25] Culhane JF, Rauh VA, Goldenberg RL. Stress bacterial vaginosis and the role of immune process. Curr Infect Dis Rep 2006;8(6):459-64.

[26] Doyle C, Swain WA, Ewald HA, et al. Sexually transmitted pathogens, depression and other manifestations associated with premenstrual syndrome. Hum Nat 2015;26(3):277-91.

[27] Rajaratnam A, Kuruvilla TS, Antony B. Significance of direct smear examination for the diagnosis of female genital tract infections. IJABPT 2011;2(4):393-8.

[28] Dagli SS and Demir T. Comparison of cervico-vaginal colonization among sexually active women by intrauterine device use. J Infect Dev Ctries 2015;9(9):930-5.

[29] Powell AM, Nyirjesy P. Recurrent vulvovaginitis. Best Pract Res Clin J Obstet Gynecol 2014;28(7):967-76. 